\title{
Pelatihan Pengelolaan Dana Investasi Pendidikan Anak Dalam Rumah Tangga Di Persit Kartika Chandra Kirana Ranting 4 Pal Cab 4 PD V / Diponegoro
}

\author{
Training of Management of Household Investment Fund in Persit Kartika Chandra \\ Kirana Ranting 4 Pal Cab 4 PD V/Diponegoro
}

\author{
Listiyowati, Iin Indarti \\ STIE Widya Manggala, Semarang \\ tiyox banget@yahoo.com, iinindarti91@,ymail.com
}

Riwayat Artikel: Dikirim 16 Maret 2019; Diterima 25 November 2019; Diterbitkan 30 November 2019

\begin{abstract}
Abstrak
Keberhasilan pengelolaan keuangan sebenarnya lebih banyak ditentukan oleh keberhasilan mengatur pengeluaran, karena kekuatan kontrol setiap pengeluaran biasanya lebih besar dari daya kontrol terhadap penghasilan. Sehingga dibutuhkan tingkat kedisiplinan didalam setiap kontrol pengeluaran. Tonggak keberhasilan kontrol pengeluaran adalah ibu rumah tangga sebagai tonggak pemegang keuangan didalam rumah tangga. Hal ini dialami oleh ibu-ibu rumah tangga di Persit Kartika Chandra Kirana Ranting 4 Pal Cab 4 PD V / Diponegoro, dimana masih kesulitan didalam melakukan pengelolaan keuangan untuk pendidikan anak. Apakah dana pendidikan ini harus disimpan sebagai tabungan atau investasi. Padahal biaya pendidikan anak semakin lama semakin meningkat seiring dengan dengan tingkat inflasi $\pm 15-16 \%$. Dengan minimnya kesadaran tentang pengelolaan dana untuk pendidikan pada ibu-ibu rumah tangga di Persit. Kegiatan PKM yang dilakukan adalah menentukan tujuan keuangan, mengumpulkan informasi dan data, memeriksa kondisi keuangan, membuat rencana keuangan, melaksanakan rencana-rencana keuangan, dan review target. Pada kelompok pengeluaran di buatlah akun investasi dana pendidikan yang nantinya dana ini akan digunakan untuk membiayai pendidikan di kemudian hari. Hasil dari program Pengabdian Kepada Masyarakat adalah peningkatan kemampuan ibu-ibu rumah tangga di Persit Kartika Chandra Kirana Ranting 4 Pal Cab 4 PD V / Diponegoro didalam mengelola keuangan mereka khususnya pengeluaran dana investasi pendidikan dengan penuh kehatihatian.
\end{abstract}

Kata kunci: ibu rumah tangga, perencanaan keuangan rumah tangga, investasi dana pendidikan.

\begin{abstract}
The success of financial management is actually more determined by the success of managing expenditure, because the power of control of each expenditure is usually greater than the power of control over income. So it takes the level of discipline in every expenditure control. The milestone of spending control is the housewife as a financial holder in the household. This is experienced by housewives in Persit Kartika Chandra Kirana Twig 4 Pal Cab 4 PD V / Diponegoro, where there are still difficulties in carrying out financial management for children's education. Does this education fund have to be saved as savings or investment. Even though the cost of children's education is increasingly increasing along with the inflation rate of $\pm 15-16 \%$. With the lack of awareness about managing funds for education in housewives in Persit. PKM activities undertaken are determining financial goals, gathering information and data, checking financial conditions, making financial plans, implementing financial plans, and reviewing targets. In the expenditure group an account is created for investment education funds which later these funds will be used to finance education in the future. The result of the Community Service Program is the improvement of the ability of housewives in Persit Kartika Chandra Kirana Twigs 4 Pal Cab 4 PD V / Diponegoro in managing their finances especially the expenditure of education investment funds with caution
\end{abstract}

Keywords: housewives, bousehold financial planning, education fund investment.

\section{PENDAHULUAN}

\section{Latar Belakang}

Kebutuhan manusia semakin lama bukan semakin murah, semakin sedikit, semakin sederhana tetapi semakin banyak, mahal beragam bahkan kompleks. Sehingga dibutuhkan skala prioritas untuk memenuhi setiap kebutuhan yang ada. Sehingga 
dibutuhkan sebuah pengelolaan yang tepat untuk menghindari istilah "besar pasak daripada tiang". Keberhasilan pengelolaan keuangan sebenarnya lebih banyak ditentukan oleh keberhasilan mengatur pengeluaran, karena kekuatan kontrol kita terhadap pengeluaran adalah lebih besar dari daya kontrol kita terhadap penghasilan kita. Hal terkecil adalah memulainya dari sektor keuangan rumah tangga. Apabila pengelolaan keuangan rumah tangga mampu dikelola dengan baik maka secara langsung juga akan berdampak terhadap kesejahteraan keluarga dan diharapkan mampu memberikan tingkat pertumbuhan masyarakat pada suatu negara.

Titik tolak keberhasilan sebuah pengelolaan keuangan yang dalam hal ini adalah keuangan rumah tangga ini adalah tingkat "kedisiplinan" pada masing-masing individu. Dan untuk rumah tangga, pihak yang sering melakukan pengelolaan keuangan adalah sosok "Ibu". Oleh karena itu sukses dan tidaknya sebuah rumah tangga yang dilihat dari sisi tingkat pengelolaan keuangan adalah terletak pada sosok seorang ibu, dengan dukungan anggota keluarga yang lain pula. Kemampuan mendisiplinkan diri untuk menempatkan kebutuhan diatas keinginan dalam rumah tangga merupakan tugas seorang ibu sebagai "menteri keuangan". Tugasnya adalah mengurus keluarga dan mengatur keuangan bulanan yang diberikan suami untuk memenuhi kebutuhan keluarga. Dalam mengelola keuangan keluarga, pendapatan memang penting, tapi pengeluaran lebih penting lagi, jika tidak bisa mengendalikan pengeluaran dengan baik, gaji sebesar apapun tidak akan cukup.

Pengelolaan keuangan dalam rumah tangga yang terpenting adalah pada sisi pengeluaran. Siklus keuangan yang terpenting dalam rumah tangga adalah mengatur arus kas, membuat perencanaan keuangan rumah tangga, mengatur investasi dan mengecek kesehatan keuangan. Pentingnya pencatatan arus kas masuk dan keluar sangat penting untuk mengetahui jumlah pengeluaran. Salah satu cara untuk memenuhi kebutuhan-kebutuhan diatas salah satunya adalah dengan investasi. Berinvestasi tidak sama dengan meletakkan sejumlah dana pada suatu instrumen investasi dan berharap akan terjadi kenaikan atas investasi kita.

Investasi yang perlu diperhatikan dalam rumah tangga adalah investasi untuk dana pendidikan anak karena semakin tahun biaya pendidikan akan semakin naik seiring dengan laju inflasi negara. Dalam mempersiapkan tujuan keuangan, faktor inflasi memang sangat penting untuk diperhitungkan karena negara kita termasuk negara dengan karakter inflasi yang dinamis. Setiap tahun kita mengalami inflasi sebagai akibat perkembangan ekonomi makro. Angka ini dapat dilihat di laporan Biro Pusat Statistik Indonesia yang diterbitkan setiap awal bulan, untuk hasil perhitungan inflasi bulan sebelumnya. Dalam perencanaan keuangan diharapkan investasi dana pendidikan sudah mulai dimasukkan kedalam pengeluaran rutin (pokok) dalam keuangan rumah tangga.

Menghadapi tingginya kenaikan biaya pendidikan, banyak orang tua mempersiapkan sejak dini. Survey membuktikan bahwa cara yang paling banyak dipilih orang tua adalah tabungan pendidikan anak. Dikarenakan ada beberapa alasan yaitu mempunyai resiko rendah, mudah prosesnya dan produk keuangan mudah dikenal. Tetapi untuk mencapai dana pendidikan yang semakin naik apabila hanya dengan tabungan saja maka orang tua akan kepayahan. Hasil dari tabungan adalah jumlah yang ditabung dikalikan bunga. Karena bunga tabungan pendidikan anak berada dibawah laju kenaikkan biaya pendidikan, satu-satunya cara memenuhi biaya pendidikan adalah meningkatkan jumlah yang ditabung. Sehingga dibutuhkan tindakan lain yaitu investasi.

Sasaran utama PKM ini adalah ibu-ibu rumah tangga terutama di Persit Kartika Chandra Kirana Ranting 4 Pal Cab 4 PD V / Diponegoro. Minimnya informasi yang 
didapatkan mengakibatkan rendahnya tingkat kesadaran dalam melakukan investasi dana pendidikan. Dimana sebelumnya hanya melalui sarana tabungan yang hanya mendapatkan tingkat pengembalian yang tidak mampu menutup kenaikan dana pendidikan. Dan untuk menghindari investasi bodong dan untuk mengetahui resiko-resiko dalam berinvestasi maka dibutuhkan informasi yang lengkap. Ketika semua informasi sudah lengkap maka baru bisa diputuskan ingin menggunakan pilihan investasi yang sesuai keinginan.

Pentingnya PKM ini adalah untuk meningkatkan pengetahuan dan keterampilan serta melatih dalam malakukan perencanaan dan pengelolaan keuangan. Selain itu PKM ini bertujuan sebagai salah satu bentuk kegiatan Tri Dharma Perguruan Tinggi dan mengajarkan pelatihan pengelolaan dana investasi untuk pendidikan anak bagi ibu rumah tangga dimana merupakan salah satu bentuk partisipasi kampus STIE Widya Manggala dalam memberikan contoh dalam perencanaan keuangan khususnya investasi dana pendidikan dan menerapkan model perencanaan keuangan untuk investasi sehingga kendala biaya pendidikan anak untuk masuk sekolah yang lebih tinggi bisa di atasi.

\section{METODE}

Kegiatan ini dilaksanakan dengan menyampaikan teori dasar tentang pengelolaan perencanaan keuangan bagi ibu rumah tangga secara sederhana dengan tujuan untuk mudah dipahami dan diaplikasikan oleh ibu ibu rumah tangga PERSIT Kartika Chandra Kirana Ranting 4 Pal. Cabang 4 PD IV Diponegoro. Setelah peserta pelatihan mengetahi konsep dasar perencanaan keuangan kemudian dilanjutkan dengan memberikan contoh pengelolaan dana anggaran dari arus kas sederhana. Dari arus kas sederhana ini maka akan didapatkan kelompok kelompok kebutuhan yang primer sampai yang tersier.
Dari pembentukan kelompok kebutuhan tersebut, akan diketahui surplus atau defisitnya. Dari anggaran kebutuhan yang sudah dibuat khusus untuk investasi akan bisa ditunjukkan, berapa jumlah dana yang akan masuk ke sub investasi.

Metode pelatihan menggunakan kertas kerja sederhana untuk penyusunan anggaran masing-masing ibu rumah tangga sehingga peserta akan langsung praktek dan menghitung sendiri tingkat pendapatan dan pengeluaran yang ada, dan pada akhirnya setelah penyusunan kertas kerja ini selesai maka peserta akan mengetahui tingkat kesehatan keuangan rumah tangganya dan kemudian dilakukan evaluasi kedepannya.

\section{HASIL DAN PEMBAHASAN}

\section{Perencanaan Pengelolaan Keuangan}

Perencanaan merupakan proses penetapan tujuan dari suatu organisasi, strategi pencapaian, tujuan organisasi serta langkahlangkah teknis yang dilakukan sehingga tujuan organisasi tersebut dapat tercapai, dengan efektif dan efisien. "Keberbasilan pengelolaan keuangan sebenarnya lebib banyak ditentukan oleh keberbasilan mengatur pengeluaran, karena kekuatan kontrol kita terbadap pengeluaran adalab lebih besar dari daya kontrol kita terhadap penghasilan kita." Penetapan prioritas kebutuhan akan sangat membantu membangun kedisiplinan dalam mengambil setiap keputusan untuk pengeluaran. Pengeluaran yang perlu dicermati adalah perencanaan dana pendidikan anak melalui investasi.

Menyikapi kenaikan terhadap kenaikan biaya pendidikan anak untuk masuk pendidikan ke tingkatan yang lebi tinggi, maka dibutuhkan pengelolaan dana untuk perihal ini. Selain menggunakan tabungan yang dianggap tidak mampu mengejar bertambahnya biaya pendidikan maka dibutuhkan pemahaman mengenai pengelolaan dana bagi ibu rumah tangga untuk berinvestasi. Tahapan-tahapan yang dilakukan untuk pengelolaan keuangan ini adalah dimulai dari penyuluhan sampai pada 
pelatihan perencanaan keuangan pada kertas kerja sederhana.

\section{Peserta, Tempat dan Kegiatan}

Peserta program pengabdian kepada masyarakat ini adalah ibu-ibu rumah tangga Persit Kartika Chandra Kirana Ranting 4 Pal Cab 4 PD V / Diponegoro. Tempat kegiatan dilaksanakan di Kodam V Diponegoro di Wilayah Banyumanik Semarang.

Kesimpulan yang dapat diperoleh dari pelaksanaan program pengabdian kepada masyarakat yang menyasar pemberdayaan dari Ibu-ibu Persit Kartika Chandra Kirana Ranting 4 Pal Cab 4 PD IV / Diponegoro, adalah:

1. Tingkat partisipasi yang tinggi dari mitra program pengabdian kepada masyarakat memberikan dampak positif bagi pelaksanaan program, hal ini terlihat dari tingkat kehadiran yang cukup tinggi.

2. Pelaksanaan program mampu menghasilkan luaran-luaran yang diharapkan oleh program pengabdian kepada masyarakat ini.

Tingginya partisipasi perserta program diharapkan mendapatkan perhatian khusus, sehingga menjadi keberlanjutan program dari kegiatan yang saat ini hanya melatih mengendalikan dan merencanaan keuangan keluarga terutama mengenai investasi pendidikan anak.

\section{Langkah-langkah}

Kegiatan dimulai dari pemberian penyuluhan, latihan membuat arus kas sederhana dan menetapkan jumah dana yang akan dipakai untuk investasi dana pendidikan.

\section{Memberikan penyuluhan}

Penelitian kesadaran tentang hakekat keuangan terutama dalam perencanaan dana investasi pendidikan anak. Pemahaman dan kemampuan untuk mengelola keuangan keluarga yang mencakup:

a. Membuat anggaran secara baik

b. Mengatur pengeluaran secara lebih baik, c. Melakukan keputusan invetasi secara baik.

Dari penyuluhan yang sudah dilakukan terjadi tanya jawab antara nara sumber (peneliti) dengan ibu-ibu persit. Dimana mereka menanyakan perihal-perihal yang terkait dengan perencanaan pengelolaan keuangan sampai pada jenis-jenis investasi pendidikan yang bisa dipercaya. Ketika informasi sudah jelas baru mereka menentukan instrumen keuangan.

Pemilihan instrumen keuangan untuk menanamkan dana pendidikan sehingga mampu mencapai target, maka langkah selanjutnya adalah mencari informasi mengenai investasi yang dipilih. Pada dasarnya semua pilihan investasi mengandung peluang keuntungan dan potensi kerugian atau resiko. Semakin besar resiko yang dimiliki oleh sebuah investasi, pada umumnya semakin besar pula keuntungan yang bisa diraih oleh investor.

Gambar 1.

Penyuluhan Pemberian Materi Terkait Perencanaan Keuangan dan Metode Pemilihan Instrumen Keuangan

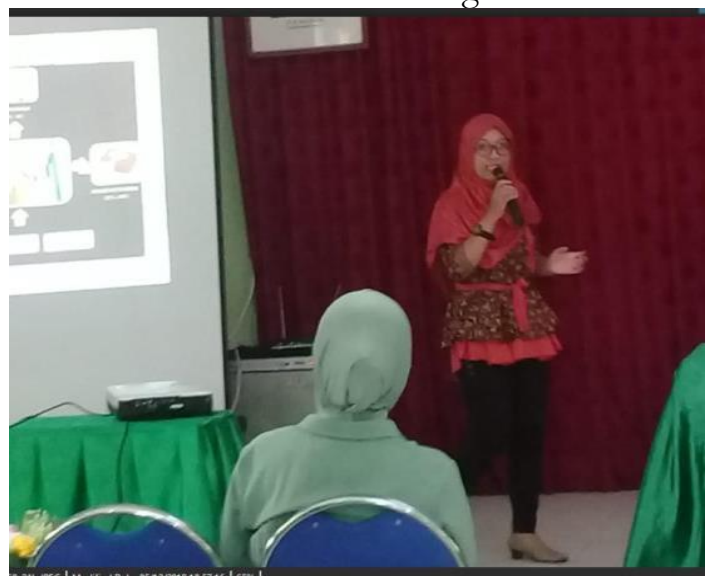

Sumber: Dokumentasi Pribadi

\section{Pelatihan Pembuatan Arus Kas Sederhana}

Sebelum berinvestasi, seorang ibu rumah tangga harus bisa mengendalikan pengeluaran. Selanjutnya memastikan kondisi keuangan keluarga berada dalam keadaan baik sehingga bisa melakukan investasi. Sebelum masuk ke pembuatan format sederhana mengelompokkan jenis 
pengeluaran peserta diberikan sedikih pemahaman mengenai kesehatan keuangan dalam rumah tangga dengan menggunakan standar keuangan rumah tangga.

Gambar 2.

Penjelasan Masing-Masing Kelompok Format

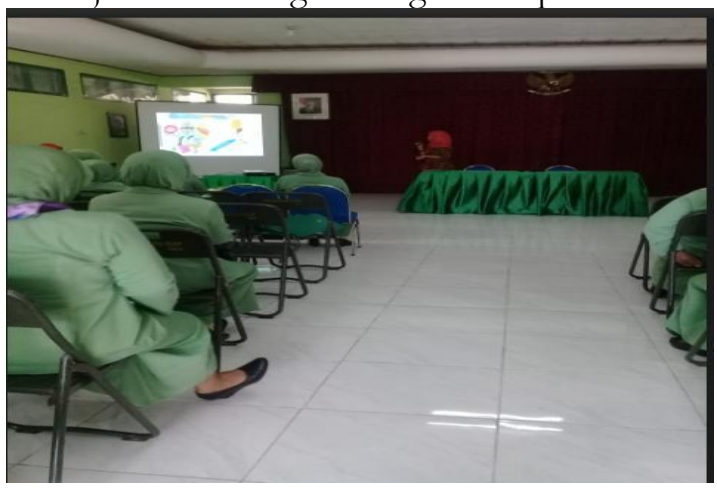

Sumber : Dokumentasi Pribadi

Tabel 1.

Rasio Kesehatan Keuangan Rumah Tangga

\begin{tabular}{|c|c|}
\hline Rasio & Standar \\
\hline $\begin{array}{c}\text { Likuiditas (Dana Darurat) } \\
\text { Kas + Setara Kas }\end{array}$ & \multirow[t]{2}{*}{$3-6$ kali } \\
\hline$\overline{\text { Kebutuhan Pengeluaran Bulanan }}$ & \\
\hline Lancar $\quad$ Kas + Setara Kas & \multirow[t]{2}{*}{$>1$} \\
\hline$\overline{\text { Hutang Jangka Pendek }}$ & \\
\hline $\begin{array}{ll}\text { Tabungan } & \\
& \text { Tabungan }\end{array}$ & \multirow[t]{2}{*}{$>10 \%$} \\
\hline Total Pendapatan & \\
\hline Hutang & \multirow[t]{2}{*}{$<50 \%$} \\
\hline$\overline{\text { Total Aset }}$ & \\
\hline $\begin{array}{l}\text { Pelunasan Hutang } \\
\text { Total Cicilan Hutang }\end{array}$ & \multirow[t]{2}{*}{$<30 \%$} \\
\hline Total Penghasilan & \\
\hline $\begin{array}{l}\text { Solvensi } \\
\text { Total Kekayaan Bersih }\end{array}$ & \multirow[t]{2}{*}{$>50 \%$} \\
\hline Total Aset & \\
\hline $\begin{array}{l}\text { Investasi } \\
\text { Total Aset Investasi }\end{array}$ & \multirow[t]{2}{*}{$>50 \%$} \\
\hline Total Aset & \\
\hline
\end{tabular}

Sumber: Kusumaningtuti, 2016
Format yang digunakan untuk membuat laporan arus kas sederhana adalah sebagai berikut:

Tabel 2.

Kelompok 1

\begin{tabular}{|l|c|}
\hline $\begin{array}{c}\text { Pengeluaran Rutin Belanja } \\
\text { Rumah Tangga }\end{array}$ & $\begin{array}{c}\text { Jumlah } \\
\text { Dianggarkan } \\
\text { (Rp) }\end{array}$ \\
\hline Membeli sayuran & \\
\hline Makan diluar / snack & \\
\hline $\begin{array}{c}\text { Kebutuhan Pribadi : } \quad \text { Pakaian } \\
\text { 2. Dry Clean }\end{array}$ & \\
3. Salon & \\
\hline $\begin{array}{l}\text { Perawatan dan Kebersihan } \\
\text { Rumah } \\
\text { Maintenance untuk perawatan } \\
\text { rumah }\end{array}$ & \\
Gaji pembantu/tukang cuci dan \\
sebagainya
\end{tabular}

Tabel 3.

Kelompok 2

\begin{tabular}{|l|c|}
\hline \multicolumn{1}{|c|}{$\begin{array}{c}\text { Pengeluaran Rutin Untuk } \\
\text { Edukasi }\end{array}$} & $\begin{array}{c}\text { Jumlah } \\
\text { Dianggarkan } \\
\text { (Rp) }\end{array}$ \\
\hline Biaya pendidikan Bulanan & \\
\hline Biaya pendidikan Lain-Lain & \\
\hline Investasi Untuk Pendidikan & \\
\hline $\begin{array}{l}\text { Total pengeluaran rutin } \\
\text { untuk edukasi }\end{array}$ & \\
\hline (dalam \%) & \\
\hline
\end{tabular}


Tabel 4

Kelompok 3

\begin{tabular}{|l|c|}
\hline $\begin{array}{c}\text { Pengeluaran Rutin Jangka } \\
\text { Panjang/Kewajiban }\end{array}$ & $\begin{array}{c}\text { Jumlah } \\
\text { Dianggarkan } \\
\text { (Rp) }\end{array}$ \\
\hline Macam-Macam Angsuran & \\
Angsuran Mobil & \\
Angsuran Motor & \\
Angsuran Rumah & \\
\hline Macam-Macam Asuransi & \\
\hline Asuransi Jiwa & \\
Asuransi Kesehatan & \\
Asuransi Kendaraan & \\
\hline Cicilan Hutang Keluarga & \\
\hline Tagihan & \\
\hline Total pengeluaran rutin & \\
jangka panjang/kewajiban & \\
\hline (dalam \%) & \\
\hline
\end{tabular}

Tabel 5.

Kelompok 4

\begin{tabular}{|l|c|}
\hline \multicolumn{1}{|c|}{$\begin{array}{c}\text { Pengeluaran Rutin Dana } \\
\text { Darurat }\end{array}$} & $\begin{array}{c}\text { Jumlah } \\
\text { Dianggarkan } \\
\text { (Rp) }\end{array}$ \\
\hline Dana untuk Tabungan & \\
\hline Dana untuk kesehatan & \\
\hline Dana Pendidikan Anak & \\
\hline Cicilan Hutang Keluarga & \\
\hline $\begin{array}{l}\text { Tagihan/pembayaran lain-lain } \\
\text { yang tidak diprediksi }\end{array}$ & \\
\hline $\begin{array}{l}\text { Total pengeluaran rutin dana } \\
\text { darurat }\end{array}$ & \\
\hline (dalam \%) & \\
\hline
\end{tabular}

Tabel 6.

Kelompok 5

\begin{tabular}{|l|l|}
\hline \multicolumn{1}{|c|}{ Entertainment \& Hobi } & $\begin{array}{c}\text { Jumlah } \\
\text { Dianggarkan } \\
\text { (Rp) }\end{array}$ \\
\hline Video / CD & \\
\hline Kaset & \\
\hline Games & \\
\hline Movie & \\
\hline Iuarn TV Kabel & \\
\hline $\begin{array}{l}\text { Pengeluaran untuk Hobi (lain- } \\
\text { lain) }\end{array}$ & \\
\hline Pengeluaran untuk Liburan & \\
\hline Total entertainment \& hobi & \\
\hline (dalam \%) & \\
\hline
\end{tabular}

Tabel 7.

Kelompok 6

\begin{tabular}{|l|c|}
\hline Pengeluaran Untuk Usaha & $\begin{array}{c}\text { Jumlah } \\
\text { Dianggarkan } \\
\text { (Rp) }\end{array}$ \\
\hline Modal Kerja & \\
\hline Modal Operasional & \\
\hline Pengembalian Cicilan Hutang & \\
\hline Pembayaran Hutang & \\
\hline Lain-lain Sumbangan & \\
\hline $\begin{array}{l}\text { Total pengeluaran untuk } \\
\text { usaha }\end{array}$ & \\
\hline (dalam \%) & \\
\hline
\end{tabular}

Tabel 8.

Kelompok 7

\begin{tabular}{|l|l|}
\hline \multicolumn{1}{|c|}{ Binatang Pemeliharaan } & $\begin{array}{c}\text { Jumlah } \\
\text { Dianggarkan } \\
\text { (Rp) }\end{array}$ \\
\hline Makanan & \\
\hline Obat-Obatan, Vitamin & \\
\hline Dokter dan sebagainya & \\
\hline Ongkos perawatan & \\
\hline Lain-lain & \\
\hline $\begin{array}{l}\text { Total pengeluaran untuk } \\
\text { binatang pemeliharaan }\end{array}$ & \\
\hline (dalam \%) & \\
\hline
\end{tabular}

Tabel 9.

Kelompok 8

\begin{tabular}{|l|l|}
\hline \multicolumn{1}{|c|}{ Medikal } & $\begin{array}{c}\text { Jumlah } \\
\text { Dianggarkan } \\
\text { (Rp) }\end{array}$ \\
\hline Dokter & \\
\hline $\begin{array}{l}\text { Obat-Obatan (Vitamin dan } \\
\text { sebagainya) }\end{array}$ & \\
\hline Klub Olahraga & \\
\hline Lain-Lain & \\
\hline $\begin{array}{l}\text { Total pengeluaran untuk } \\
\text { medikal }\end{array}$ & \\
\hline (dalam \%) & \\
\hline
\end{tabular}

\section{Menentukan Besaran Dana untuk Investasi Pendidikan}

Dari pembagian kelompok pembuatan arus kas keluar maka investasi dana pendidikan diberlakukan sebagai pengeluaran wajib. Ketika semua pengeluaran sudah dihitung maka langkah berikutnya adalah menghitung surplus/defisitnya. Jika terjadi surplus (pengeluaran $<$ penghasilan) maka dana sisa tersebut bisa ditambahkan sebagai investasi dana pendidikan. Tetapi jika terjadi defisit 
(pengeluaran $>$ penghasilan) maka bisa diambilkan ke kebutuhan tersier bukan mengurangi dana investasi pendidikan, karena sudah diberlakukan wajib.

Untuk mencari surplus (defisit) adalah sebagai berikut:

\begin{tabular}{|c|c|}
\hline PENERIMAAN & (PENDAPATAN \\
\hline Penerimaan Rutin & $=\operatorname{Rp} \ldots \ldots \ldots \ldots \ldots \ldots \ldots \ldots$ \\
\hline Penerimaan Lain-Lain & $=\mathrm{Rp} \ldots$ \\
\hline TOTAL PENERIMAAN & $=\mathbf{R p}$. \\
\hline ANGGARAN PENGELU & ARAN \\
\hline Kelompok 1 & $=\mathrm{Rp} \ldots$ \\
\hline Kelompok 2 & $=R p \ldots$ \\
\hline Kelompok 3 & $=\mathrm{Rp} \ldots . .$. \\
\hline Kelompok 4 & $=\operatorname{Rp}$ \\
\hline Kelompok 5 & $=R p \ldots$ \\
\hline Kelompok 6 & $=R p \ldots$ \\
\hline Kelompok 7 & $=\mathrm{Rp} \ldots \ldots$ \\
\hline Kelompok 8 & $=\operatorname{Rp} \ldots \ldots \ldots \ldots \ldots \ldots \ldots$ \\
\hline TOTAL ANGGARAN & $=\underline{R} \ldots \ldots \ldots \ldots \ldots \ldots \ldots \ldots$ \\
\hline SURPLUS/(DEFISIT) & $=\underline{R} \ldots \ldots \ldots \ldots \ldots \ldots \ldots \ldots \ldots$ \\
\hline
\end{tabular}

\section{KESIMPULAN}

Kesimpulan yang dapat diperoleh dari pelaksanaan program pengabdian kepada masyarakat yang menyasar pemberdayaan dari Ibu-ibu Persit Kartika Chandra Kirana Ranting 4 Pal Cab 4 PD IV / Diponegoro, adalah:

1. Peserta mengetahui informasi-informasi yang terkait dengan jenis-jenis investasi dan bagaimana untuk menghindari investasi bodong yang marak di masyarakat;

2. Peserta mampu membuat perencanaan keuangan sederhana dan menentukan kondisi kesehatan keuangan rumah tangga;

3. Peserta mampu mengetahui arus defisit dan surplus rencana keuangan mereka dan ;

4. Melatih kedisiplinan peserta untuk sadar untuk tetap melakukan simpanan bagi pendidikan anak.

\section{DAFTAR PUSTAKA}

Chandra, Teddy. (2016). Investasi Bagi Pemula. Pekanbaru: Zifatama Publishing.

Soetiono, Kusumaningtuti S (2016), Perencanaan Keuangan, Jakarta: Ikatan Akuntan Indonesia.

Mengelola Kuangan Keluarga, 7 Jurus Jitu Strategi Investasi, www.duitku.com.

Business Strategy and Personal Development. 9 Cara Cerdas Mengelola Keuangan Pribadi. www.strategimanajemen.com.

UU Pasar Modal No. 8 tahun 1995. 